\title{
Concentrations and Sources of Polycyclic Aromatic Hydrocarbons in the Seawater around Langkawi Island, Malaysia
}

\author{
Essam Nasher, ${ }^{1}$ Lee Yook Heng, ${ }^{1,2}$ Zuriati Zakaria, $^{3}$ and Salmijah Surif ${ }^{1}$ \\ ${ }^{1}$ Faculty of Science and Technology, Universiti Kebangsaan Malaysia, Selangor, 43600 Bangi, Malaysia \\ ${ }^{2}$ Southeast Asia Disaster Prevention Research Institute (SEADPRI), Universiti Kebangsaan Malaysia, Selangor, 43600 Bangi, Malaysia \\ ${ }^{3}$ Malaysia Japan International Institute of Technology, Universiti Teknologi Malaysia, Kuala Lumpur, Malaysia \\ Correspondence should be addressed to Essam Nasher; essam_abduh@yahoo.com
}

Received 12 November 2012; Revised 28 December 2012; Accepted 10 January 2013

Academic Editor: Athanasios Katsoyiannis

Copyright ( 2013 Essam Nasher et al. This is an open access article distributed under the Creative Commons Attribution License, which permits unrestricted use, distribution, and reproduction in any medium, provided the original work is properly cited.

\begin{abstract}
This paper reports the levels of polycyclic aromatic hydrocarbons (PAHs) in the water around the Island and their probable sources. Water samples were collected from four jetties and three marine fish farms around the main Langkawi Island and analysed for 18 polycyclic aromatic hydrocarbons (PAHs) in December 2010. The total PAH concentrations ranged from $6.1 \pm 0.43$ to 46 $\pm 0.42 \mu \mathrm{gL}^{-1}$, which exceed the maximum admissible concentrations of PAHs $\left(0.20 \mu \mathrm{gL}^{-1}\right)$ for the water standard of European Union. The calculated diagnostic benzo[a]anthracene : benzo[a] anthracene + chrysene ratio of between 0.52 and 1.0 suggests that the sources of PAHs at the majority of the stations studied are derived primarily from pyrogenic sources, from incomplete fuel combustion of the boats and vehicle engines, with lesser amounts of PAHs contributed from petrogenic sources. Some stations displayed mixed sources. A significant positive correlation was found between total organic carbon (TOC) and the concentrations of the high-molecular-weight PAHs $\left(r^{2}=0.86, P<0.05\right)$, which suggests significant secondary sources of PAHs, such as those from atmospheric deposition.
\end{abstract}

\section{Introduction}

The Langkawi Archipelago in the Straits of Malacca, north west of Peninsular Malaysia consists of 104 Islands, the largest and most exploited of which is Langkawi Island with an area of $478.5 \mathrm{~km}^{2}$. Targeted for ecotourism, Langkawi became a duty-free island in 1987 and is protected from industrial activity [1]. In 2006, the Island was declared a National Geopark; a year later it became an UNESCO Global Geopark [1]. In 2010, 2.4 million tourists visited Langkawi [1]. To cater for this increase in tourism-related activities, the local population swelled significantly from about 40,000 in 1991 to almost 100,000 in 2010 [2]. It is envisaged that this boost in tourism industry would significantly increase pollution in Langkawi, particularly from the boating activities which use petroleum and diesel. One of the most significant polluting components of petroleum is polycyclic aromatic hydrocarbons (PAHs).

PAHs are a group of over 100 different compounds with fused benzene rings [3], prominent in smoke, soot, and exhausts resulting from the incomplete combustion of carbon compounds, such as petroleum [4]. The environmentally significant PAHs are those molecules that contain 2 to 7 benzene rings. PAHs are divided into two groups based on their physical, chemical, and biological characteristics [5]. The lower-molecular-weight PAHs, for example, the 2 to 3 rings of PAHs such as naphthalenes, fluorenes, phenanthrenes, and anthracenes, have significant acute toxicity to aquatic organisms. The high-molecular-weight (HMW) PAHs, containing 4 to 7 rings, from chrysenes to coronenes, do not cause acute toxicity but are known to be carcinogenic [6]. Sixteen PAH compounds have been identified as priority pollutants due to their toxic, mutagenic, and carcinogenic characteristics [7]. Due to their low water solubility and high lipophilicity, PAHs are easily and rapidly absorbed by organisms and can be accumulated in aquatic organism or adsorbed onto the surface of suspended matter, get deposited on the sea floor and be passed onto the marine food chain. 


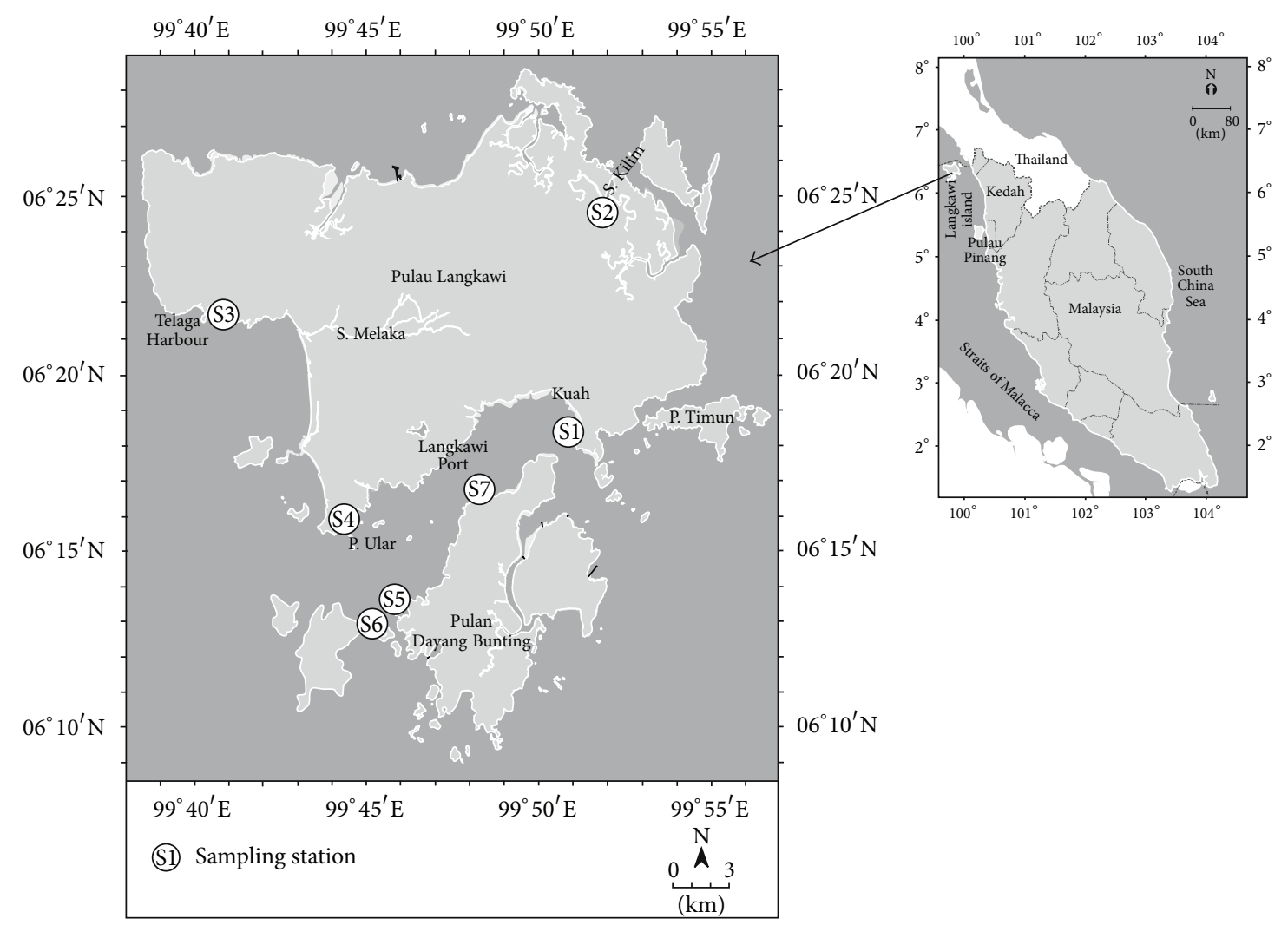

FIGURE 1: Map showing the seven sampling stations (S1-S7) around Langkawi Island, Malaysia.

Sources of PAHs can be either petrogenic, from petroleum-related activities or pyrogenic (pyrolytic), from the incomplete combustion of diesel fuel and engine oil [8], wood, coal, biomass of forest, grass fires, waste incinerators, and fossil fuels that are used in industrial operations and power plants [9-12]. PAHs are also widely used in commercial products, such as intermediaries in pharmaceuticals, agricultural products, photographic products, thermosetting plastics, and lubricating materials.

In the marine environment, the pollution from PAHs can result from natural seepage or land-based sources, from river discharges, urban runoff, refineries and other industrial wastewater [6], or from sea-based sources, such as two-stroke vessel discharge, nontank vessel spills, operational discharge, gross atmospheric deposition, and aircraft dumping [13]. These possible sources of PAHs can be differentiated by their respective diagnostic ratios [14]. A phenanthrene-toanthracene ratio (Phe/Ant) of $>15$ indicates that the PAHs are petrogenic, whereas a ratio of $<10$ shows that they are pyrolytic in origin [15].

Few studies have been done on the concentration of hydrocarbons in the water and the sediment of Langkawi Island. Law and Hii [16] reported that the hydrocarbon (polycyclic compounds and PAHs) concentrations in the seawater at Pulau Payar, to the south of Langkawi Island ranged from 32 to $46 \mu \mathrm{g} \mathrm{L}^{-1}$ which is lower than the contamination level of hydrocarbons $\left(50 \mu \mathrm{g} \mathrm{L}^{-1}\right)$ in the tropical sea [16]. The total PAHs in sediments collected from Langkawi Island after an oil spill accident ranged from 34 to $2.7 \times 10^{2} \mu \mathrm{g} \mathrm{kg}^{-1}$ [17]
Abdullah [18] reported a high level of total hydrocarbons in the sediments of Langkawi Island, up to $8.5 \times 10^{2} \mathrm{mg} \mathrm{kg}^{-1}$, which is higher than the safety level $\left(1.0 \times 10^{2} \mathrm{mg} \mathrm{kg}^{-1}\right)$ [19]. The high level was attributed to the oil spilled by the collision between the supertanker Nagasaki Spirit and the container Ocean Blessing off of Belawan in 1992. The tar balls collected from Langkawi Island had a higher PAH content (up to $4.7 \times$ $10^{2} \mu \mathrm{g} \mathrm{g}^{-1}$ ), compared to most of samples collected from the west and east coasts of Malaysia, as reported by Zakaria et al. [20]. In fact, the Langkawi Island is considered to be the third most polluted coastal area by oil and grease in Malaysia which may lead to the increase in the levels of aliphatic and aromatic compounds [21,22].

There is an increasing in the pressure on the fragile ecosystem of Langkawi Island due to the tourism activities that are being aggressively promoted by the Malaysian government. In particular, the marine environment may be receiving more and more loading from hydrocarbon pollutants from the increasing boating activities from marine ecotourism. So far, there is no reported impact study from the tourism sector for Langkawi. Therefore, the purpose of this study is to assess the concentration, distribution, and potential sources of PAHs in Langkawi Island.

\section{Methodology}

2.1. Study Area. Water was sampled from seven stations: Telaga Harbour, Kilim Jetty, Porto Malai Jetty, Kuah Jetty and Fish Farms I, II, and III in December 2010. Figure 1 
TABLE 1: Sampling locations and associated water depths (meter).

\begin{tabular}{lccccc}
\hline No. & Station code & Station name & Depth & Latitude (N) & Longitude (E) \\
\hline 1 & S1 & Kuah Jetty & 3 & $6^{\circ} 18^{\prime} 22.9^{\prime \prime}$ & $99^{\circ} 51^{\prime} 02.0^{\prime \prime}$ \\
2 & S2 & Kilim Jetty & 1 & $6^{\circ} 24^{\prime} 18.4^{\prime \prime}$ & $99^{\circ} 51^{\prime} 31.0^{\prime \prime}$ \\
3 & S3 & Telaga Harbour & 3 & $6^{\circ} 22^{\prime} 03.6^{\prime \prime}$ & $99^{\circ} 41^{\prime} 07.0^{\prime \prime}$ \\
4 & S4 & Porto Malai Jetty & 3 & $6^{\circ} 15^{\prime} 57.5^{\prime \prime}$ & $99^{\circ} 44^{\prime} 13.3^{\prime \prime}$ \\
5 & S5 & Fish Farm I & 7 & $6^{\circ} 13^{\prime} 12.9^{\prime \prime}$ & $99^{\circ} 46^{\prime} 07.8^{\prime \prime}$ \\
6 & S6 & Fish Farm II & 8 & $6^{\circ} 12^{\prime} 48.0^{\prime \prime}$ & $99^{\circ} 45^{\prime} 42.5^{\prime \prime}$ \\
7 & S7 & Fish Farm III & 8 & $6^{\circ} 16^{\prime} 39.6^{\prime \prime}$ & $99^{\circ} 48^{\prime} 15.2^{\prime \prime}$ \\
\hline
\end{tabular}

and Table 1 show the sampling stations with their associated water depths. These sampling stations were chosen based on their unique activities: Telaga Harbour is a terminal jetty for sailing boats and the yachts, while Kilim Jetty and Porto Malai Jetty are both starting points for marine ecotourism activities including eagle feeding, coastal bat cave exploration, visits to fish farms, and trips to the limestone landscape and the mangrove forests. Kuah Jetty is the main terminal for ferries from mainland Kuala Kedah and Penang as well as Thailand and Singapore. Fish Farms I, II, and III are chosen to represent the many fish farms and finfish aquacultures in the coastal water surrounding Langkawi Island that are frequented by tourists and for providing fresh seafood to the restaurants.

Water samples $(1 \mathrm{~L})$ were collected in precleaned glass bottles at $0.00-0.30 \mathrm{~m}$ from the surface. They were then sealed with aluminium foil to avoid photooxidation and kept at $\mathrm{pH} \approx 2.0$ by adding $\mathrm{HCl}(12 \mathrm{M})$ to prevent degradation of the hydrocarbons [35]. The samples were kept at $4^{\circ} \mathrm{C}$ in ice during transportation and then kept cool at $-4^{\circ} \mathrm{C}$ until analysed. During sampling, several water quality parameters (temperature, $\mathrm{pH}$, conductivity, total dissolved solid, and salinity) were measured in situ, using a surveyor 4a instrument (HACH, USA).

2.2. Chemicals and Reagent. A standard mixture of PAHs consisting of naphthalene (Nap), 1-methylnaphthalene (1MNap), 2-methylnaphthalene (2MNap), acenaphthylene (Acy), acenaphthene (Ace), fluorene (Fl), phenanthrene (Phe), anthracene (Ant), fluoranthene (Flu), pyrene (Pyr), benz[a]anthracene $(\mathrm{BaA})$, chrysene $(\mathrm{Chr})$, benzo[b]fluoranthene $(\mathrm{BbF})$, benzo[k]fluoranthene $(\mathrm{BkF})$, benzo[a]pyrene $(\mathrm{BaP})$, indeno[1,2,3-cd]pyrene (InP), dibenzo[ah]anthracene (DBA), and benzo[ghi]perylene (BgP) was purchased from Restek Corporation, USA. The $p$-terphenyl-d14 ( $p$-Ter) (Supelco, USA) was used as the surrogate internal standard. The standards were further diluted with hexane to prepare five calibration standard mixtures. Dichloromethane (DCM), n-hexane, acetone, and cyclohexane, which were all of chromatographic grade, in addition to HPLC-grade distilled pentane, were obtained from Merck, Germany.

\subsection{Chemical Analysis}

2.3.1. Sample Extraction. The extraction of organic pollutants from the whole seawater sample was performed according to the US EPA method 610 [36] with slight modification, and the clean-up process following that was as described in the
EPA method 3630C [37]. Briefly, a $250 \mathrm{~mL}$ sample was spiked with $1 \mathrm{~mL}$ of surrogate standard $p$-terphenyl-d14 $(2 \mathrm{ng} / \mu \mathrm{L})$; a $30 \mathrm{~mL}$ of dichloromethane (DCM) was added. The sample was agitated in a digital shaker for $6 \mathrm{hrs}$, followed by shaking in an ultrasonic bath for a further 5 min to extract any organic pollutants that may have been adsorbed onto the wall of the flask. The mixture was then transferred into a separation funnel and left for $5 \mathrm{~min}$ to separate the water from the organic solvent layer. The bottom DCM layer containing the hydrocarbons was decanted into a $250 \mathrm{~mL}$ round-bottomed flask, and the extraction was process repeated three times. The combined extract was then allowed to mix with granule activated copper overnight to remove any sulphur contaminants, passed the extract through a glass column containing $5 \mathrm{~g}$ anhydrous $\mathrm{Na}_{2} \mathrm{SO}_{4}$ (activated at $400^{\circ} \mathrm{C}$ for $4 \mathrm{~h}$ before use) to remove any residual water, and concentrated to $3 \mathrm{~mL}$ using a rotary evaporator. Cyclohexane $(10 \mathrm{~mL})$ was then added as an exchange solvent, and the extract was concentrated to $2 \mathrm{~mL}$ by rotary evaporator. The extract was then passed through a glass column containing $5 \mathrm{~g}$ activated silica gel (previously activated by heating at $200^{\circ} \mathrm{C}$ for $16 \mathrm{~h}$ before use) and $1 \mathrm{~g}$ of anhydrous $\mathrm{Na}_{2} \mathrm{SO}_{4}$. The PAH fraction was then eluted using a $30 \mathrm{~mL}$ mixture of DCM : pentane $(2: 3, \mathrm{v} / \mathrm{v})$ and concentrated to $2 \mathrm{~mL}$ using a rotary evaporator. Hexane $(10 \mathrm{~mL})$ was added as an exchange solvent [37], and it was evaporated down to $2 \mathrm{~mL}$. The extract was finally reduced to $1 \mathrm{~mL}$ under a gentle stream of nitrogen gas. All sample extracts were kept in amber glass vials at $-4^{\circ} \mathrm{C}$ until analysed within a week.

The extract $(1 \mu \mathrm{L})$ was injected into Gas Chromatography (Agilent technologies, USA) equipped with a flame ionization detector (FID) [38]. A fused silica TR-5MS capillary column $(30 \mathrm{~m} \times 0.25 \mathrm{~mm}$ i.d.) with film thickness of $0.25 \mu \mathrm{m}$ (Thermo Fisher, USA) was used in the column separation. High-purity helium (99.9\%) was used as a carrier gas, makeup gas, and purge gas at flow rates of $1.0,45$, and $30 \mathrm{~mL} / \mathrm{min}$, respectively. The flow rates for the FID were $450 \mathrm{~mL} / \mathrm{min}$ and $45 \mathrm{~mL} / \mathrm{min}$ for air and hydrogen, respectively. The gas chromatograph was operated in splitless mode and separation was conducted with the oven temperature programmed as follows: initial setting at $80^{\circ} \mathrm{C}(1 \mathrm{~min}$ hold $)$, ramped to $180^{\circ} \mathrm{C}$ at $10^{\circ} \mathrm{C} / \mathrm{min}$ (for $2 \mathrm{~min}$ ), and, finally, to $320^{\circ} \mathrm{C}$ at $5^{\circ} \mathrm{C} / \mathrm{min}$ ( $10 \mathrm{~min}$ hold). The injector was held at $250^{\circ} \mathrm{C}$ and the FID maintained at $350^{\circ} \mathrm{C}$. Agilent Chemstation software was used to obtain the chromatogram and for data calculations. An external standard calibration comprising $18 \mathrm{PAH}$ standards was used to determine the identity and quantity of each component peak in sample chromatogram. 
TABLE 2: Concentrations of 18 PAHs in the seawater around Langkawi Island $\left(\mu \mathrm{gL}^{-1}\right)$.

\begin{tabular}{lccccccc}
\hline PAH & Kuah Jetty & Kilim Jetty & Telaga Harbour & Porto Malai Jetty & Fish F. I & Fish F. II & Fish F. III \\
\hline Nap & $6.4 \pm 0.55$ & $3.1 \pm 0.66$ & $2.1 \pm 0.12$ & $4.8 \pm 0.12$ & $1.8 \pm 0.11$ & $2.5 \pm 0.55$ & $7.8 \pm 0.16$ \\
lMNap & $2.4 \pm 0.067$ & $0.39 \pm 0.033$ & $0.87 \pm 0.073$ & $2.9 \pm 0.15$ & $\mathrm{nd}^{\mathrm{a}}$ & $\mathrm{nd}^{\mathrm{a}}$ & $7.0 \pm 0.15$ \\
2MNap & $2.7 \pm 0.095$ & $\mathrm{nd}^{\mathrm{a}}$ & $\mathrm{nd}^{\mathrm{a}}$ & $0.64 \pm 0.069$ & $\mathrm{nd}^{\mathrm{a}}$ & $\mathrm{nd}^{\mathrm{a}}$ & $1.8 \pm 0.14$ \\
Acy & $1.3 \pm 0.063$ & $1.7 \pm 0.11$ & $0.44 \pm 0.12$ & $1.4 \pm 0.023$ & $0.62 \pm 0.21$ & $0.67 \pm 0.15$ & $4.1 \pm 0.12$ \\
Ace & $4.2 \pm 0.16$ & $1.8 \pm 0.040$ & $0.49 \pm 0.022$ & $3.7 \pm 0.044$ & $0.46 \pm 0.040$ & $0.35 \pm 0.12$ & $3.3 \pm 0.090$ \\
Fl & $0.22 \pm 0.037$ & $\mathrm{nd}^{\mathrm{a}}$ & $0.35 \pm 0.041$ & $\mathrm{nd}^{\mathrm{a}}$ & $0.27 \pm 0.074$ & $\mathrm{nd}^{\mathrm{a}}$ & $0.46 \pm 0.028$ \\
Phe & $0.24 \pm 0.055$ & $0.55 \pm 0.018$ & $\mathrm{nd}^{\mathrm{a}}$ & $0.27 \pm 0.040$ & $\mathrm{nd}^{\mathrm{a}}$ & $0.57 \pm 0.018$ & $0.37 \pm 0.055$ \\
Ant & $0.27 \pm 0.056$ & $0.88 \pm 0.056$ & $\mathrm{nd}^{\mathrm{a}}$ & $0.34 \pm 0.082$ & $\mathrm{nd}^{\mathrm{a}}$ & $0.32 \pm 0.019$ & $\mathrm{nd}$ \\
Flu & $0.76 \pm 0.019$ & $\mathrm{nd}$ & $\mathrm{nd}^{\mathrm{a}}$ & $0.86 \pm 0.020$ & $1.4 \pm 0.11$ & $1.5 \pm 0.013$ & $0.49 \pm 0.056$ \\
Pyr & $0.53 \pm 0.037$ & $2.8 \pm 0.075$ & $\mathrm{nd}^{\mathrm{a}}$ & $0.55 \pm 0.0051$ & $0.91 \pm 0.093$ & $1.8 \pm 0.02$ & $1.7 \pm 0.28$ \\
BaA & $1.2 \pm 0.046$ & $4.7 \pm 0.25$ & $0.40 \pm 0.025$ & $1.3 \pm 0.050$ & $1.9 \pm 0.16$ & $4.1 \pm 0.23$ & $3.3 \pm 0.10$ \\
Chr & $0.88 \pm 0.023$ & $11 \pm 0.069$ & $\mathrm{nd}^{\mathrm{a}}$ & $1.1 \pm 0.050$ & $0.80 \pm 0.046$ & $4.0 \pm 0.23$ & $2.7 \pm 0.069$ \\
BbF & $\mathrm{nd}^{\mathrm{a}}$ & $0.69 \pm 0.053$ & $\mathrm{nd}^{\mathrm{a}}$ & $\mathrm{nd}$ & $0.95 \pm 0.053$ & $\mathrm{nd}$ & $0.84 \pm 0.040$ \\
BkF & $\mathrm{nd}^{\mathrm{a}}$ & $0.59 \pm 0.11$ & $\mathrm{nd}^{\mathrm{a}}$ & $\mathrm{nd}^{\mathrm{a}}$ & $0.42 \pm 0.080$ & $\mathrm{nd}$ & $0.79 \pm 0.19$ \\
BaP & $0.45 \pm 0.055$ & $0.68 \pm 0.056$ & $\mathrm{nd}^{\mathrm{a}}$ & $\mathrm{nd}^{\mathrm{a}}$ & $1.1 \pm 0.028$ & $0.98 \pm 0.028$ & $0.91 \pm 0.17$ \\
InP & $\mathrm{nd}^{\mathrm{a}}$ & $0.29 \pm 0.031$ & $\mathrm{nd}^{\mathrm{a}}$ & $\mathrm{nd}^{\mathrm{a}}$ & $0.50 \pm 0.13$ & $0.96 \pm 0.031$ & $\mathrm{nd}$ \\
DBA & $0.72 \pm 0.031$ & $1.6 \pm 0.13$ & $0.65 \pm 0.034$ & $0.96 \pm 0.068$ & $4.3 \pm 0.094$ & $5.1 \pm 0.31$ & $4.2 \pm 0.19$ \\
BgP & $2.5 \pm 0.035$ & $4.4 \pm 0.11$ & $0.78 \pm 0.039$ & $2.1 \pm 0.16$ & $2.5 \pm 0.071$ & $4.9 \pm 0.035$ & $6.4 \pm 0.42$ \\
$\sum$ PAHs & $25 \pm 0.77$ & $35 \pm 0.89$ & $6.1 \pm 0.43$ & $21 \pm 0.87$ & $18 \pm 0.43$ & $28 \pm 1.8$ & $46 \pm 0.42$ \\
\hline
\end{tabular}

${ }^{\mathrm{a}}$ Not detectable.

The total organic carbon (TOC) in seawater contains dissolved, colloidal, and particulate organic carbon [39]. A fixed volume of each water sample was acidified with concentrated $\mathrm{HCL}$ to get the $\mathrm{pH}$ down to $\leq 2$ for removing the inorganic carbons. Concentrations of TOC were determined using the high-temperature combustion method using a CHNS (O) Analyser (Thermo Finnigan, Italy) [40].

2.4. QA/QC. Replicate samples were analysed for each station to calculate the precision of measurements. The method blank containing the solvent and surrogate internal standard underwent analysis to evaluate the contamination of solvents, reagents, and the glassware that was used. The accuracy of the analytical procedure was examined through recovery of spiked water after subtraction from the unspiked water. A known amount of the PAH mixture (in acetone) was spiked into a deionized water sample and left for a few hours before being similarly extracted and analysed. The surrogate internal standard ( $p$-terphenyl-d14) was used throughout the analytical procedure to monitor the losses and contamination during the sample extraction and instrumental analysis. The average recovery of the 18 PAHs and $p$-terphenyl-d14 ranged from 70 to $120 \%$ with relative standard deviation (RSD) values being mainly less than $14 \%$, which meet the acceptance criteria of the EPA method [41], thereby indicating that the method adopted from EPA is acceptable for the analysis of PAHs in the seawater samples. The instrumental limit of detection (LOD) of individual PAHs was estimated to be $3^{*} \mathrm{~S}$, where $\mathrm{S}$ is the standard deviation of eight replicate analyses of spiked water samples [42]. The LOD was then used to calculate the method detection limit (MDL) with the following formula: $\mathrm{MDL}=\left(\mathrm{LOD} \mu \mathrm{g} \mathrm{mL}^{-1} \times\right.$ final volume in
$\mathrm{mL} /$ volume extracted in L) [43]. The MDL of the individual PAHs using the present method ranged from 0.010 to $0.49 \mu \mathrm{g} \mathrm{L}^{-1}$.

The correlation coefficient $(r)$ is a measure of the "goodness of fit" of the regression line to the data where $(r)$ must be greater than or equal to 0.99 . Five $\mathrm{PAH}$ mixture standards were run in the GC-FID on the same day of sample analysis to estimate the regression equations that were used to calculate the concentration of individual PAHs in the samples. All PAH regression equations gave a $(r)$ value of $(\geq 0.99)$ which is an acceptable value according to the EPA method 8000B [41].

2.5. Statistical Analysis. One-way ANOVA along with Games-Howell and post hoc multiple comparison tests was used to evaluate the significance of the differences between the total PAHs at the sampling stations using SPSS version 15 for Windows. Correlation Pearson's analysis was carried out to test the relationship between water quality parameters, between individual PAHs in the water, and between the total PAHs and TOC. The effect size test ( $d$ family) was used to measure the magnitude of difference between total PAHs at sampling stations, small $=0.20$, medium $=0.50$, large $=0.80$, and very large $\geq 1$ magnitude of the difference between two groups [44].

\section{Results and Discussion}

3.1. Concentration of PAHs in Surface Water. Table 2 shows the concentrations of PAHs in the seawater from the seven sampling stations. The total $\mathrm{PAH}$ concentrations vary from $6.1 \pm 0.43 \mu \mathrm{g} \mathrm{L}^{-1}$ at the Telaga Harbour to $46 \pm 0.42 \mu \mathrm{g} \mathrm{L}^{-1}$ at the Fish Farm III with a mean value of $26 \pm 13 \mu \mathrm{g} \mathrm{L}^{-1}$. These 
TABLE 3: Reported PAHs concentrations $\left(\mu \mathrm{gL}^{-1}\right)$ in the particulate and dissolved phase of surface seawater in different areas of the world.

\begin{tabular}{|c|c|c|c|c|c|}
\hline Locations & $N^{\mathrm{a}}$ & Dissolved & Particulate & $\begin{array}{c}\text { Whole water } \\
\text { (dissolved + particulate) }\end{array}$ & Reference \\
\hline Bay of Biscay, France & 18 & $8.2 \times 10^{-4}-1.7 \times 10^{-3}$ & $34-1.1 \times 10^{3}$ & $34-1.1 \times 10^{3}$ & [23] \\
\hline Leghorn, Tyrrhenian Sea, Italy & 15 & $6.3 \times 10^{-2}-3.1$ & $0.55-7.5$ & $0.61-11$ & {$[24]$} \\
\hline Yellow river delta & 16 & $0.65-0.34$ & $66-6.8 \times 10^{2}$ & $66-6.8 \times 10^{2}$ & {$[24]$} \\
\hline Jarzouna-Bizerte, Tunisia (Mediterranean Sea) & 17 & $(28-76) \times 10^{2}$ & $-{ }^{\mathrm{b}}$ & $(28-76) \times 10^{2}$ & [25] \\
\hline Redcar Jetty, England & 15 & - & - & $\mathrm{Nd}^{\mathrm{c}}-25$ & {$[26]$} \\
\hline Daliao River Estuary, Bohai Sea, China & 16 & $0.14-1.7$ & $0.23-1.4$ & $0.37-3.1$ & [27] \\
\hline Gerlache Inlet Sea, Antarctica & 13 & - & - & $(5.3-9.4) \times 10^{-4}$ & {$[28]$} \\
\hline Western Taiwan Strait, China & 15 & $0.012-0.058$ & $0.010-0.046$ & $0.022-0.10$ & {$[29]$} \\
\hline England and Wales & 15 & - & - & $\mathrm{Nd}^{\mathrm{c}}-11$ & {$[26]$} \\
\hline Baltic Sea & 15 & - & - & $7.0 \times 10^{-5}-1.7 \times 10^{-2}$ & {$[30]$} \\
\hline Macao Harbour, China & 16 & $0.092-0.26$ & $0.69-6.5$ & $0.78-6.7$ & {$[31]$} \\
\hline Xiamen Harbour, China & 16 & $0.11-0.94$ & $-{ }^{\mathrm{b}}$ & $0.11-0.94$ & {$[32]$} \\
\hline Jiulong River Estuary and Western Xiamen Sea, China & 16 & $7.0-27$ & $-{ }^{b}$ & $7.0-27$ & [33] \\
\hline Singapore Island & 16 & $0.020-8.5$ & $-{ }^{b}$ & $0.020-8.5$ & {$[34]$} \\
\hline Langkawi Island, Malaysia & 18 & - & - & $6.1-46$ & Present study \\
\hline
\end{tabular}

${ }^{\mathrm{a}}$ Number of PAHs, ${ }^{\mathrm{b}}$ not analyzed, and ${ }^{\mathrm{c}}$ not detectable.

results reflect the PAH inputs from direct discharge of boats with two-stroke engine and the deposition of fuel combustion of boats and vehicles, which were clearly observed during the sampling. The Kuah Jetty, Kilim Jetty, Porto Malai Jetty, and Telaga Harbour which are popular jetties for tourists, recorded PAH concentrations of between 6.1 and $35 \mu \mathrm{g} \mathrm{L}^{-1}$. It is likely that boating activities, especially when there is leakage of petroleum or the unscrupulous disposal of engine oil from boats and ferries [21] may contribute significantly to the level of PAHs recorded in these locations. The mean concentration of total PAHs in the water samples of Fish Farms I, II, and III were 18,28 , and $46 \mu \mathrm{g} \mathrm{L}^{-1}$, respectively. Fish Farm III (S7) recorded the highest concentration of PAHs. This could be due to it being located near the busy stretch of water between the main island of Langkawi with the smaller Dayang Bunting Island and the numerous associated port activities, such as shipping and boating which could contribute to PAHs in the sediment and water. Leaching processes and biological activity in sediment may return a small amount of PAHs to the water column [6]. McIntosh et al. [45] also reported that boat engines are one of the main sources of PAHs in fish farms.

The total PAH levels at the jetties, harbour, and fish farms are significantly higher than the maximum admissible concentrations of the European Union of $0.20 \mu \mathrm{g} \mathrm{L}^{-1}$ and the Environmental Quality Criteria of the United States, $\sum$ PAHs $=0.030 \mu \mathrm{g} \mathrm{L}^{-1}$ for protection of human consumers of aquatic life [46]. In addition, water with total PAH concentrations above $10 \mu \mathrm{g} \mathrm{L}^{-1}$ can be ranked as heavily contaminated by $\mathrm{PAH}$ pollutants [23]. The total concentration of PAHs in water at Telaga Harbour station $\left(6.1 \mu \mathrm{g} \mathrm{L}^{-1}\right)$ was lower than $10 \mu \mathrm{g} \mathrm{L}^{-1}$, but it was higher than the maximum admissible concentrations. In as much as the jetties and fish farm stations recorded concentrations of more than $10 \mu \mathrm{gL}^{-1}$ (Table 2), certain organisms, especially the fish, in these locations are likely to have been exposed to rather high levels of PAHs during their life time.

The most frequently detected PAHs in the water samples were naphthalene (16\%), acenaphthylene (6\%), acenaphthene (8\%), benzo[a]anthracene (9\%), dibenzo[ah] anthracene (10\%), and benzo[ghi]perylene (13\%). The mean concentration of individual PAHs including carcinogenic and noncarcinogenic PAHs, in all samples ranged from 0.22 to $11 \mu \mathrm{g} \mathrm{L}^{-1}$. These are either within or higher than that of the Annual Average Environmental Quality Standards (AA-EQS) of European Water Framework Directive (WFD) for individual PAHs, which state that the safe range for PAHs is from $2.0 \times 10^{-2}$ to $2.4 \mu \mathrm{g} \mathrm{L}^{-1}$ [47]. The mean concentrations of seven carcinogenic PAHs with high molecular weight (BaA, Chr, BbF, BkF, BaP, DBA, and InP) ranged from 0.44 to $3.4 \mu \mathrm{g} \mathrm{L}^{-1}$ with a mean of $1.5 \mu \mathrm{g} \mathrm{L}^{-1}$, accounting for $36 \%$ of total PAHs in all water samples. These results are higher than the safe limits of the EPA National Recommended Water Quality Criteria for the protection of aquatic life and human health $\left(0.020 \mu \mathrm{g} \mathrm{L}^{-1}\right)$ [46]. Benzo[a]pyrene (BaA), the most carcinogenic pollutant of all PAHs [48], was detected in all fish farms samples, with concentrations ranging from 0.91 to $1.1 \mu \mathrm{g} \mathrm{L}^{-1}$ (a mean of $1.0 \mu \mathrm{g} \mathrm{L}^{-1}$ ). The levels were higher than those of the EPA National Recommended Water Quality Criteria for the protection of aquatic life $\left(0.010 \mu \mathrm{g} \mathrm{L}^{-1}\right)$ [46], which could have an adverse ecological effect in these areas, particularly for the fish.

As shown in Table 3, the PAH concentrations in the whole surface seawater of Langkawi Island were approximately 1 order of magnitude lower than water from Bay of Biscay, France [23] and about 1 to 2 orders of magnitude lower than water from Jarzouna Coast, Bizerte, Tunisia [25] and in the Yellow River Delta, China [24]. Additionally, they were nearly 
TABLE 4: Correlation coefficient between individual PAH concentrations.

\begin{tabular}{|c|c|c|c|c|c|c|c|c|c|c|c|c|c|c|c|c|c|c|}
\hline & Nap & M1Nap & M2Nap & Acy & Ace & $\mathrm{Fl}$ & Phe & Ant & FIu & Pyr & $\mathrm{BaA}$ & Chr & $\mathrm{BbF}$ & $\mathrm{BkF}$ & $\mathrm{BaP}$ & InP & DBA & $\mathrm{BgP}$ \\
\hline Nap & 1 & & & & & & & & & & & & & & & & & \\
\hline $1 \mathrm{MNap}$ & $0.90^{* *}$ & 1 & & & & & & & & & & & & & & & & \\
\hline 2MNap & $0.88^{* *}$ & 0.66 & 1 & & & & & & & & & & & & & & & \\
\hline Acy & $0.82^{*}$ & $0.91^{* *}$ & 0.52 & 1 & & & & & & & & & & & & & & \\
\hline Ace & $0.87^{*}$ & 0.67 & $0.83^{*}$ & 0.56 & 1 & & & & & & & & & & & & & \\
\hline $\mathrm{Fl}$ & 0.34 & 0.54 & 0.37 & 0.41 & 0.03 & 1 & & & & & & & & & & & & \\
\hline Phe & 0.22 & 0.08 & 0.00 & 0.35 & 0.14 & -0.56 & 1 & & & & & & & & & & & \\
\hline Ant & -0.11 & -0.32 & -0.18 & -0.04 & 0.13 & $-0.77^{*}$ & 0.69 & 1 & & & & & & & & & & \\
\hline FIu & -0.15 & -0.21 & -0.05 & -0.28 & -0.18 & -0.24 & 0.04 & -0.27 & 1 & & & & & & & & & \\
\hline Pyr & 0.02 & -0.01 & -0.20 & 0.39 & -0.10 & -0.36 & $0.82^{*}$ & 0.68 & -0.07 & 1 & & & & & & & & \\
\hline $\mathrm{BaA}$ & 0.00 & -0.02 & -0.23 & 0.36 & -0.17 & -0.37 & $0.86^{*}$ & 0.60 & 0.05 & $0.98^{* *}$ & 1 & & & & & & & \\
\hline Chr & -0.11 & -0.19 & -0.28 & 0.21 & -0.09 & -0.50 & $0.76^{*}$ & $0.87^{*}$ & -0.32 & $0.92^{* *}$ & $0.86^{*}$ & 1 & & & & & & \\
\hline $\mathrm{BbF}$ & 0.04 & 0.20 & -0.11 & 0.47 & -0.14 & 0.36 & -0.03 & -0.04 & -0.03 & 0.50 & 0.42 & 0.33 & 1 & & & & & \\
\hline $\mathrm{BkF}$ & 0.29 & 0.45 & 0.04 & 0.74 & 0.05 & 0.37 & 0.22 & 0.08 & -0.26 & 0.64 & 0.56 & 0.48 & $0.92^{* *}$ & 1 & & & & \\
\hline $\mathrm{BaP}$ & -0.05 & -0.04 & -0.06 & 0.23 & -0.32 & 0.10 & 0.32 & -0.04 & 0.51 & 0.60 & 0.65 & 0.31 & 0.67 & 0.57 & 1 & & & \\
\hline InP & -0.57 & -0.59 & -0.53 & -0.40 & -0.67 & -0.46 & 0.41 & 0.17 & 0.66 & 0.44 & 0.56 & 0.29 & 0.06 & -0.09 & 0.65 & 1 & & \\
\hline DBA & -0.10 & 0.04 & -0.22 & 0.20 & -0.44 & 0.10 & 0.30 & -0.26 & 0.64 & 0.44 & 0.56 & 0.09 & 0.48 & 0.40 & $0.88^{* *}$ & 0.72 & 1 & \\
\hline $\mathrm{BgP}$ & 0.44 & 0.47 & 0.18 & 0.73 & 0.11 & 0.04 & 0.74 & 0.20 & 0.12 & $0.79^{*}$ & $0.84^{*}$ & 0.53 & 0.47 & 0.68 & 0.69 & 0.32 & 0.67 & 1 \\
\hline
\end{tabular}

** Correlation is significant at the 0.01 level ( 2 tailed). ${ }^{*}$ Correlation is significant at the 0.05 level ( 2 tailed).

similar to the levels presented in the dissolved water of Jiulong River Estuary and Western Xiamen Sea, China [33] and water from the Jetty of Redcar, England [26].

However, the total PAHs of Langkawi water were approximately 1 to 2 orders of magnitude higher than those detected in some of the nearby water systems, such as the dissolved water of Singapore Island [34], Daliao River Estuary in Bohai Sea, China [27], and Macao Harbour of China [31] (Table 4). Furthermore, they were 3 to 4 orders of magnitude higher than those found in Gerlache Inlet Sea, Antarctica [28] and Baltic Sea [30]. The 2006 annual report of the Malaysian Department of Environment ranked Langkawi Island third in terms of areas being polluted by oil and grease among the 15 monitoring stations in Peninsula Malaysia that exceeded the water quality standard by $80 \%$ [21].

There was a significant difference (ANOVA, $P<0.05$ ) in the mean concentrations of total PAHs in the water from the fish farms, the jetties, and the Telaga Harbour stations $(P=0.01 ; P=0.001$, resp. $)$. However, there was no significant difference in the total PAHs between the fish farms and jetties $(P=0.82)$. Telaga Harbour is only used as a terminal point for yachts with a lot less boating activities than either the jetties or the fish farms. Thus, these results suggest that the PAH inputs in these stations could come from the direct discharge of petroleum products as well as the dry and wet deposition of fuel combustion. To calculate the consistent value of differences between these stations, the effect size ( $d$ family), which measures the magnitude of the differences of mean concentrations of total PAHs between sites, was estimated for the fish farms, jetties, and harbour stations. The $d$ values for the fish farms were 0.37 orders of magnitude higher than the seawater from the jetties and 2.1 orders of magnitude higher than the seawater of the harbour station. However, the jetties were 3.5 orders of magnitude higher than the harbour station, which indicates that the fish farms and jetties have higher orders of magnitude compared to the harbour station.

3.2. PAH Composition. The composition pattern of PAHs by ring size for the water samples around Langkawi Island is shown in Figure 2. The high-molecular-weight PAHs of four rings (Flu, Pyr, $\mathrm{BaA}$, and $\mathrm{Chr}$ ), five rings (BbF, $\mathrm{BkF}$, $\mathrm{BaP}$, and $\mathrm{DBA}$ ) and six rings ( $\mathrm{InP}, \mathrm{BgP}$ ) generally account for $28 \%, 15 \%$, and $14 \%$ of the total PAH concentrations, respectively. The water samples of Kilim Jetty and Fish Farms I and II were dominated by HMW-PAHs (4-6 rings), representing the range of $76-84 \%$, which are likely derived from anthropogenic activities [49], such as incomplete fuel combustion of the boats, ships, and vehicle engines. However, the lower-molecular-weight PAHs of two rings (1MNap, 2MNap, and Nap) and three rings (Acy, Ace, Fl, Phe, and Ant) made up $26 \%$ and $17 \%$ of the total PAH concentrations, respectively. LMW-PAHs (2-3 rings) were the most abundant components in water samples from Kuah, Porto Malai Jetties and Telaga Harbour, with a range between 67 and $72 \%$. The results suggest a relatively recent local PAHs source which entered into the seawater due to the inefficient two-stroke outboard engines of most boats in Langkawi Island that usually involve the discharge to the water of about $20 \%$ of fuel without burning [50]. The water sample from Fish Farm III represented an approximately equal content of HMW-PAHs (46\%) and LMW-PAHs (54\%) (Figure 3), which probably reflects both anthropogenic activities and recent local PAH sources due to the tourism boats and ships activities of 


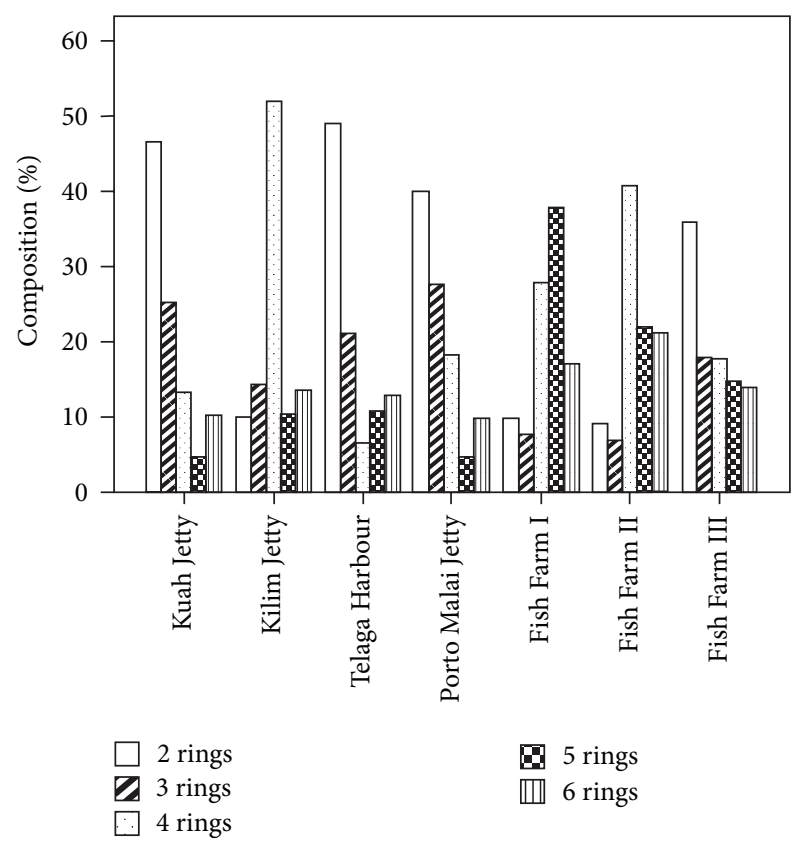

FIGURE 2: Composition pattern (\%) of PAHs by the number of rings: 2-,3-,4-,5-, and 6-ring PAH.

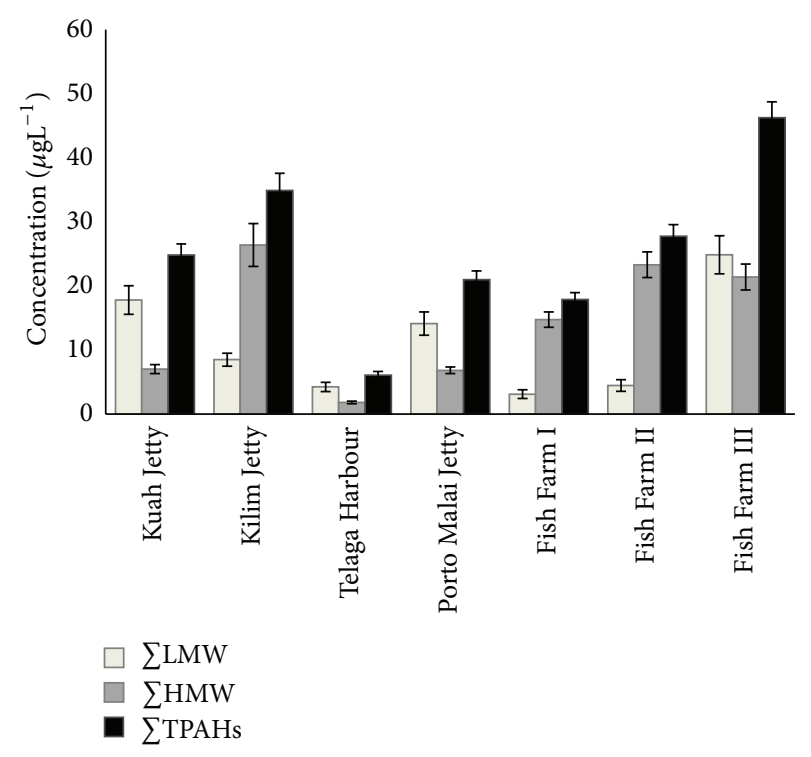

Figure 3: The total of HMW, LMW, and PAHs concentrations $\left(\mu \mathrm{g} \mathrm{L}^{-1}\right)$ in seawater from different sampling stations.

Langkawi port that are located in front of this farm. The results of the paired samples $t$-test of LMW to HMWPAHs show no significant difference between the LMW- and HMW-PAHs in the water of Langkawi Island $(P=0.54)$, suggesting the importance of both LMW- and HMW-PAH inputs in the water of Langkawi.

For individual PAHs, the highest concentration measured in the seawater samples was chrysene $\left(11 \mu \mathrm{g} \mathrm{L}^{-1}\right)$ at Kilim Jetty. This high concentration of chrysene is perhaps due to its very low solubility in water that permits it to be adsorbed onto the surface of suspended matter and its high resistance to degradation. The study reported by Wang et al. [51] found that the level of chrysene did not significantly change after 12 years of oil spill, which reflects the resistance of chrysene in aquatic environment and its high increase compared to others. Benzo[ghi]perylene ( $\mathrm{BgP})$, a compound that has the fingerprint of a combustion engine and which is more abundant in soot [10], was found to have the second highest mean concentration for individual PAHs $\left(3.4 \mu \mathrm{g} \mathrm{L}^{-1}\right)$ in the water samples of Langkawi Island. A study by Omar et al. [49] also supported the phenomenon of BgP emission coming from engines. The study mentioned that the highest abundance of BgP was recorded in the urban aerosols of Kuala Lumpur, Malaysia and that incomplete fuel combustion was its source. Therefore, the amount of $\mathrm{BgP}$ measured in this study was most probably related to the incomplete fuel combustion of the boats and vehicle engines that were extensively used in the Island.

The total organic carbon (TOC) of seawater represents the content of dissolved and particulate organic matter (in carbonaceous form). The mean concentration of TOC in seawater for all stations studied ranged from 0.030 to $1.8 \%$. A positive significant correlation between the TOC content and total concentrations of HMW-PAHs $\left(r^{2}=0.83, P<\right.$ 0.05) in the whole seawater was observed. Due to their high hydrophobic nature, PAHs tend to get adsorbed onto the surface of suspended matter. Such a correlation is an indication that the high molecular weight of PAHs determined from the seawater samples is from secondary sources, such as the atmospheric deposition of soot particles that are characterized by HMW-PAHs [52], which are probably due to the fuel combustion of tourism boats, ships, fishing ships, and vehicles. This correlation is similar to that found in Daliao River Estuary water of Liaodong Bay, Bohai Sea, China [27].

3.3. Identification of PAH Sources. The difficulty in identifying the PAH sources relies on many factors. The possible coexistence of many origins of pollutants and the transformation process that PAHs can undergo before or after deposition to sediment [53]. The correlation factor values approach and diagnostic ratios can be used to identify the possible sources of PAHs. The correlation factor value is a statistical approach that is used depending on the fact that each pollution source produces a characteristic $\mathrm{PAH}$ pattern, which means that it can be applied to assess the linear dependence of the individual PAHs. Therefore, the correlation factor between the water concentrations for all the individual PAHs can give an idea of whether they all originate from the same or different sources. Table 4 shows the correlation between the individual PAHs. There is a positive correlation among the LMW PAHs $\left(0.52<r^{2}<0.91\right)$, except Fl, Phe, Ant, and among the HMW PAHs $\left(0.06<r^{2}<0.98\right)$, except Flu and BkF. The weaker correlations between LMW PAHs compared to the HMW PAHs support that their sources are dissimilar and imply that there are probably at least two sources of PAHs: petrogenic and pyrogenic. Correspondingly, these results were in agreement with the findings by Itoh et al. [54]. The strongest relationships among the LMW PAHs 
TABLE 5: Diagnostic PAH ratios in seawater and their possible sources.

\begin{tabular}{lccc}
\hline Station & $\mathrm{BaA} / \mathrm{BaA}+\mathrm{Chr}^{\mathrm{a}}$ & $\mathrm{Phe} / \mathrm{Ant}^{\mathrm{b}}$ & LMW/HMW $^{\mathrm{c}}$ \\
\hline Kuah Jetty & 0.57 & 0.87 & 2.5 \\
Kilim Jetty & 0.31 & 0.62 & 0.32 \\
Telaga Harbour & 1.0 & $\mathrm{NC}^{\mathrm{d}}$ & 2.3 \\
Porto Malai Jetty & 0.55 & 0.80 & 2.1 \\
Fish F. I & 0.70 & $\mathrm{NC}^{\mathrm{d}}$ & 0.21 \\
Fish F. II & 0.50 & 1.8 & 0.19 \\
Fish F. III & 0.55 & $\mathrm{NC}^{\mathrm{d}}$ & 1.2 \\
Mean & 0.60 & 1.1 & 1.3 \\
Petrogenic sources & $<0.20$ & $>15$ & $>1$ \\
Pyrogenic sources & $>0.35$ & $<10$ & $<1$
\end{tabular}

${ }^{a}$ benzo[a]anthracene to benzo[a]anthracene plus chrysene ratio.

${ }^{\mathrm{b}}$ phenanthrene to anthracene ratio; ${ }^{\mathrm{c}}$ lower-molecular-weight PAHs to highmolecular-weight PAHs ratio; ${ }^{d}$ not calculated due to the concentration of one of ratio variables being undetectable.

was between M1Nap and Acy $\left(r^{2}=0.91, P<0.01\right)$, while among HMW PAHs it was between Pyr with BaA $\left(r^{2}=0.98\right.$, $P<0.01)$. The significant correlation between the LMW PAHs and HMW PAHs was between Phe and $\operatorname{Pyr}\left(r^{2}=0.82\right)$, $\operatorname{BaA}\left(r^{2}=0.86\right)$ and $\mathrm{Chr}\left(r^{2}=0.76\right)$, and between Ant and $\mathrm{Chr}\left(r^{2}=0.87\right)$. Thus, the strong correlation of these PAHs may suggest that they originated from a common source that is widely distributed in the investigated location.

As mentioned above, there were at least two sources of PAHs. To elucidate the details of PAH sources in the water samples, diagnostic ratios were applied, which are a useful tool to distinguish the petrogenic and pyrogenic sources of PAH in different media of the environment depending on their physical, chemical properties and stability against photolysis [55]. The petrogenic source is a result of the direct input from petroleum and its products, while the pyrogenic sources are a result of incomplete combustion of fossil fuels (i.e., exhausts of vehicles) [10, 11].

Various PAH congener ratios that display the best potential to distinguish between the petrogenic and pyrogenic sources and the most consistently quantifiable compounds in the majority of these samples were selected as indication, for example, the ratios of (Phe/Ant) and $(\mathrm{BaA} / \mathrm{BaA}+\mathrm{Chr})$ $[15,55]$. Table 5 shows the diagnostic ratios of some PAH compounds. The ratios of Phe/Ant, which are lower than 10 , are seen as characteristic of the combustion processes, whereas values higher than 10 indicate petroleum input or diagenetic [56]. The ratios of Phe/Ant found in this study, which were between 0.62 and 1.8 (mean 1.1), suggest that the PAHs are from combustion sources. Possible contributing sources in the Island are from incomplete fuel combustion of the boats and vehicle engines.

In addition, the ratio $(\mathrm{BaA} / \mathrm{BaA}+\mathrm{Chr})$ of $<0.20$ usually implies petrogenic origin, $0.20-0.35$ indicates mixed petrogenic and pyrogenic origin, while $>0.35$ indicates pyrogenic origin [55]. Hence, the values of this ratio from the seawater samples ranged from 0.52 to $1.0($ mean $=0.60)$ (Table 5). They were above 0.35 for all samples with the exception of the water samples from Kilim Station (ratio $=0.34$ ), which might reflect mixed inputs from the direct discharge of two-stroke engine boats and the deposition of fuel combustion of boats and vehicles.

The calculated ratios for the LMW/HMW for all stations were between 0.32 and 2.5 (mean 1.3), which suggests that the sources of PAHs were both pyrogenic (ratio of $<1$ ) and petrogenic (ratio of $>1$ ) [53]. Some stations, such as Kuah Jetty and Telaga Harbour, derived their PAHs from both sources (Table 5).

However, this generally suggests that PAHs can be largely attributed to combustion with a contribution from petrogenic sources. Distinguishing the sources of PAHs by the diagnostic ratios chosen could reveal the inputs of the pyrogenic material. Moreover, the diminution of the level of high-molecularweight PAHs compared to low-molecular-weight PAHs in some stations can also reflect a lesser amount contributed by petrogenic sources due to the direct discharge of unburned fuel of the two-stroke engine boats.

3.4. Correlation between the PAH Levels and the Physicochemical Characteristics of Water. Physicochemical properties of the sea water (TDS, temperature, conductivity, $\mathrm{pH}$, salinity, and dissolved oxygen) and their relationship to the PAH concentrations were measured (see Supplementary Material S1, available online at: http://dx.doi.org/10.1155/2013/975781). The mean temperature of the seawater for all stations studied ranged from 28.6 to $29.2^{\circ} \mathrm{C}$, with a conductivity 49 to $51 \mu \mathrm{S} \mathrm{cm}^{-1}$, total dissolved solid (TDS) 29.8 to $30.5 \mathrm{mg} \mathrm{L}^{-1}$, $\mathrm{pH}$ from 7.3 to 8.0 , salinity from 30.2 to $30.3 \%$, and dissolved oxygen from 4.0 to $5.8 \mathrm{mg} \mathrm{L}^{-1}$. Generally, these levels of water parameters in the sampling stations were in the good range for water quality guidelines of the European Water Framework Directive (WFD). The dissolved oxygen levels in the seawater surrounding the fish farms were lower than the equilibrium value of $6.4 \mathrm{mg} \mathrm{L}^{-1}$ [57], but were sufficiently high for fish aquaculture activities. These observations indicate that the seawater bodies around Langkawi Island are within the normal range. Moreover, possible relationship analysis among water quality parameters was carried out. A significant positive correlation was noticed between TDS and conductivity $\left(r^{2}=0.97, P<0.001\right)$ and between TDS and salinity $\left(r^{2}=0.61\right)$. This correlation reflects that seawater has the same type and nature of dissolved cations and anions. There is a good positive correlation between temperature and LMW-PAHs $\left(r^{2}=0.74\right)$, suggesting that temperature has an effect on the aqueous solubility of PAHs as higher temperatures cause more PAHs to be soluble in the water [6].

\section{Conclusion}

The concentrations of PAHs in water samples collected from jetties and the tourism fish farms were approximately two to three orders of magnitude higher than those in the harbour. This implies that all the samples exceeded the maximum admissible concentrations of PAHs $\left(0.20 \mu \mathrm{g} \mathrm{L}^{-1}\right)$ according to the water standard of the European Union and may cause toxicity to certain exposed organisms. The significant 
correlation between TOC and the high molecular weight of PAHs $\left(r^{2}=0.83, P<0.05\right)$ indicate the importance of secondary sources of PAHs (e.g., combustion-derived PAH); the diagnostic PAH ratios indicate that PAHs can be largely attributed to pyrogenic (pyrolytic) sources with a lesser amount contributed by petrogenic source, which is possibly due to the nonburning fuel discharge of the inefficient twostroke engines of Langkawi boats. Some stations displayed mixed sources.

\section{Acknowledgments}

This work was financially supported by Grants nos. UKMST-06-FRGS0245-2010 and UKM-OUP-PLW-11-48/2010 and Grant UKM-Arus Perdana on Langkawi Geopark. Herewith, all the authors declare and acknowledge that this paper is original and has been written by the stated authors who are all aware of its content and approve its submission. This paper has not been published previously nor is under consideration for publication elsewhere. No conflict of interests exists.

\section{References}

[1] LADA, Langkawi Development Authority Report, 2011.

[2] N. Samat, "Assessing land use land cover changes in Langkawi island: towards sustainable urban living," Malaysian Journal of Environmental Management, vol. 11, no. 1, pp. 48-57, 2010.

[3] M. C. Wei and J. F. Jen, "Determination of polycyclic aromatic hydrocarbons in aqueous samples by microwave assisted headspace solid-phase microextraction and gas chromatography/flame ionization detection," Talanta, vol. 72, no. 4, pp. 12691274, 2007.

[4] A. Katsoyiannis, A. J. Sweetman, and K. C. Jones, "PAH molecular diagnostic ratios applied to atmospheric sources: a critical evaluation using two decades of source inventory and air concentration data from the UK," Environmental Science and Technology, vol. 45, no. 20, pp. 8897-8906, 2011.

[5] E. Martinez, M. Gros, S. Lacorte, and D. Barceló, "Simplified procedures for the analysis of polycyclic aromatic hydrocarbons in water, sediments and mussels," Journal of Chromatography A, vol. 1047, no. 2, pp. 181-188, 2004.

[6] J. M. Neff, Polycyclic Aromatic Hydrocarbons in the Aquatic Environment: Sources, Fates, and Biological Effects, Applied Science Publishers, 1979.

[7] N. F. Y. Tam, L. Ke, X. H. Wang, and Y. S. Wong, "Contamination of polycyclic aromatic hydrocarbons in surface sediments of mangrove swamps," Environmental Pollution, vol. 114, no. 2, pp. 255-263, 2001.

[8] M. Szewczynska, M. Posniak, and E. Dobrzynska, "Study on individual PAHs content in ultrafine particles from solid fractions of diesel and biodiesel exhaust fumes," Journal of Chemistry, vol. 2013, Article ID 528471, 10 pages, 2013.

[9] M. W. Ashraf, S. I. H. Taqvi, A. R. Solangi, and U. A. Qureshi, "Distribution and risk assessment of polycyclic aromatic hydrocarbons in vegetables grown in Pakistan," Journal of Chemistry, vol. 2013, Article ID 873959, 5 pages, 2013.

[10] R. Boonyatumanond, M. Murakami, G. Wattayakorn, A. Togo, and H. Takada, "Sources of polycyclic aromatic hydrocarbons (PAHs) in street dust in a tropical Asian mega-city, Bangkok,
Thailand," Science of the Total Environment, vol. 384, no. 1-3, pp. 420-432, 2007.

[11] E. Y. Zeng and C. L. Vista, "Organic pollutants in the coastal environment off San Diego, California. 1. Source identification and assessment by compositional indices of polycyclic aromatic hydrocarbons," Environmental Toxicology and Chemistry, vol. 16, no. 2, pp. 179-188, 1997.

[12] E. Caylak, "Health risk assessment for trace metals, polycyclic aromatic hydrocarbons and trihalomethanes in drinking water of Cankiri, Turkey," Journal of Chemistry, vol. 9, no. 4, pp. 19761991, 2012.

[13] NRC, National ReSearch Council, Oil in the Sea III: Inputs, Fates, and Effectsed, National Academies Press, Washington, DC, USA, 2003.

[14] A. Katsoyiannis, E. Terzi, and Q. Y. Cai, "On the use of PAH molecular diagnostic ratios in sewage sludge for the understanding of the PAH sources. Is this use appropriate?" Chemosphere, vol. 69, no. 8, pp. 1337-1339, 2007.

[15] Z. Zhang, J. Huang, G. Yu, and H. Hong, "Occurrence of PAHs, PCBs and organochlorine pesticides in the Tonghui River of Beijing, China," Environmental Pollution, vol. 130, no. 2, pp. 249-261, 2004.

[16] A. T. Law and Y. S. Hii, "Status, impacts and mitigation of hydrocarbon pollution in the Malaysian seas," Aquatic Ecosystem Health and Management, vol. 9, no. 2, pp. 147-158, 2006.

[17] M. S. Ibrahim, Z. Din, and N. Abdullah, "Extent of hydrocarbon pollution in Langkawi. A study on $\mathrm{PAH}$ pollution after the major oil spill in 1992," Malaysian Journal of Analytical Sciences, vol. 2, pp. 115-122, 1996.

[18] M. P. Abdullah, "Hydrocarbon pollution in the sediment of some Malaysian coastal areas," Environmental Monitoring and Assessment, vol. 44, no. 1-3, pp. 443-454, 1997.

[19] P. L. Bishop, Marine Pollution and Its Control, McGraw-Hill Book Company, New York, NY, USA, 1983.

[20] M. P. Zakaria, T. Okuda, and H. Takada, "Polycyclic aromatic hydrocarbon (PAHs) and hopanes in stranded tar-balls on the coasts of Peninsular Malaysia: applications of biomarkers for identifying sources of oil pollution," Marine Pollution Bulletin, vol. 42, no. 12, pp. 1357-1366, 2001.

[21] DOE, Malaysia Environmental Quality Report, 2005, 2006.

[22] S. L. Tong, S. H. Goh, A. R. Abdulah, N. M. Tahir, and C. W. Wang, "ASEAN marine water quality criteria for oil and grease," Marine Environment Division, Water quality management Bureau, Pollution control department. ASEANCANADA Cooperative programme on Marine Science, 1999.

[23] J. Tronczyński, C. Munschy, K. Héas-Moisan et al., "Contamination of the Bay of Biscay by polycyclic aromatic hydrocarbons (PAHs) following the T/V "Erika" oil spill," Aquatic Living Resources, vol. 17, no. 3, pp. 243-259, 2004.

[24] L. Wang, Z. Yang, J. Niu, and J. Wang, "Characterization, ecological risk assessment and source diagnostics of polycyclic aromatic hydrocarbons in water column of the Yellow River Delta, one of the most plenty biodiversity zones in the world," Journal of Hazardous Materials, vol. 169, no. 1-3, pp. 460-465, 2009.

[25] I. Zrafi-Nouira, Z. Khedir-Ghenim, R. Bahri, I. Cheraeif, M. Rouabhia, and D. Saidane-Mosbahi, "Hydrocarbons in seawater and water extract of Jarzouna-Bizerte coastal of Tunisia (Mediterranean Sea): petroleum origin investigation around refinery rejection place," Water, Air, and Soil Pollution, vol. 202, no. 1-4, pp. 19-31, 2009. 
[26] R. J. Law, V. J. Dawes, R. J. Woodhead, and P. Matthiessen, "Polycyclic aromatic hydrocarbons (PAH) in seawater around England and Wales," Marine Pollution Bulletin, vol. 34, no. 5, pp. 306-322, 1997.

[27] B. Men, M. He, L. Tan, C. Lin, and X. Quan, "Distributions of polycyclic aromatic hydrocarbons in the Daliao River Estuary of Liaodong Bay, Bohai Sea (China)," Marine Pollution Bulletin, vol. 58, no. 6, pp. 818-826, 2009.

[28] A. M. Stortini, T. Martellini, M. Del Bubba, L. Lepri, G. Capodaglio, and A. Cincinelli, " $n$-Alkanes, PAHs and surfactants in the sea surface microlayer and sea water samples of the Gerlache Inlet sea (Antarctica)," Microchemical Journal, vol. 92, no. 1, pp. 37-43, 2009.

[29] Y. L. Wu, X. H. Wang, Y. Y. Li, and H. S. Hong, "Occurrence of polycyclic aromatic hydrocarbons (PAHs) in seawater from the Western Taiwan Strait, China," Marine Pollution Bulletin, vol. 63, no. 5-12, pp. 459-463, 2011.

[30] G. Witt, "Occurrence and transport of polycyclic aromatic hydrocarbons in the water bodies of the Baltic Sea," Marine Chemistry, vol. 79, no. 2, pp. 49-66, 2002.

[31] X. Luo, B. Mai, Q. Yang, J. Fu, G. Sheng, and Z. Wang, "Polycyclic aromatic hydrocarbons (PAHs) and organochlorine pesticides in water columns from the Pearl River and the Macao harbor in the Pearl River Delta in South China," Marine Pollution Bulletin, vol. 48, no. 11-12, pp. 1102-1115, 2004.

[32] J. L. Zhou, H. Hong, Z. Zhang, K. Maskaoui, and W. Chen, "Multi-phase distribution of organic micropollutants in Xiamen Harbour, China," Water Research, vol. 34, no. 7, pp. 2132-2150, 2000.

[33] K. Maskaoui, J. L. Zhou, H. S. Hong, and Z. L. Zhang, "Contamination by polycyclic aromatic hydrocarbons in the Jiulong River Estuary and Western Xiamen Sea, China," Environmental Pollution, vol. 118, no. 1, pp. 109-122, 2002.

[34] K. K. Chee, M. K. Wong, and H. K. Lee, "Determination of polycyclic aromatic hydrocarbons in sea water using solidphase microextraction," International Journal of Environmental Studies, vol. 56, no. 5, pp. 689-701, 1999.

[35] S. K. Kim, D. S. Lee, W. J. Shim, U. H. Yim, and Y. S. Shin, "Interrelationship of pyrogenic polycyclic aromatic hydrocarbon (PAH) contamination in different environmental media," Sensors, vol. 9, no. 12, pp. 9582-9602, 2009.

[36] USEPA, EPA-Method 610, Polynuclear Aromatic Hydrocarbons, 2010.

[37] USEPA, EPA-Method 3630C, Silica Gel Cleanup, 1996.

[38] USEPA, EPA-method 8100, Polycyclic Aromatic Hydrocarbons, 1986.

[39] L. Guo, T. Tanaka, D. Wang, N. Tanaka, and A. Murata, "Distributions, speciation and stable isotope composition of organic matter in the southeastern Bering Sea," Marine Chemistry, vol. 91, no. 1-4, pp. 211-226, 2004.

[40] Guo Laodong, C. H. Coleman Jnr, and P. H. Santschi, "The distribution of colloidal and dissolved organic carbon in the Gulf of Mexico," Marine Chemistry, vol. 45, no. 1-2, pp. 105-119, 1994.

[41] USEPA, EPA, Method 8000B, Determinative Chromatographic Separations, 1996.

[42] R. K. Smith, Handbook of Environmental Analysis, Genium publishing, 1999.

[43] J. R. M. Ross and D. R. Oros, "Polycyclic aromatic hydrocarbons in the San Francisco Estuary water column: sources, spatial distributions, and temporal trends (1993-2001)," Chemosphere, vol. 57, no. 8, pp. 909-920, 2004.
[44] J. Cohen, Statistical Power, Taylor and Francis Group, 2nd edition, 1988.

[45] A. D. McIntosh, L. Webster, P. J. Hayes, and C. F. Moffat, "The source and fate of polycyclic aromatic hydrocarbons (PAHs) in sediment and water from Loch Leven," FRS Marine Laboratory, Aberdeen Report 02 2, 2002.

[46] EPA, Environmental Protection Agency United States, National Recommended Water Quality Criteria, 2009.

[47] F. Werres, P. Balsaa, and T. C. Schmidt, "Total concentration analysis of polycylic aromatic hydrocarbons in aqueous samples with high suspended particulate matter content," Journal of Chromatography A, vol. 1216, no. 12, pp. 2235-2240, 2009.

[48] H. S. Wang, P. Liang, Y. Kang et al., "Enrichment of polycyclic aromatic hydrocarbons (PAHs) in mariculture sediments of Hong Kong," Environmental Pollution, vol. 158, no. 10, pp. 32983308, 2010.

[49] N. Y. M. J. Omar, M. R. B. Abas, N. A. Rahman, N. M. Tahir, A. I. Rushdi, and B. R. T. Simoneit, "Levels and distributions of organic source tracers in air and roadside dust particles of Kuala Lumpur, Malaysia," Environmental Geology, vol. 52, no. 8, pp. 1485-1500, 2007.

[50] T. D. Mosisch and A. H. Arthington, "Polycyclic aromatic hydrocarbon residues in the sediments of a dune lake as a result of power boating," Lakes and Reservoirs, vol. 6, no. 1, pp. 21-32, 2001.

[51] Z. Wang, M. Fingas, and G. Sergy, "Chemical characterization of crude oil residues from an arctic beach by GC/MS and GC/FID," Environmental Science and Technology, vol. 29, no. 10, pp. 26222631, 1995.

[52] C. H. Vane, I. Harrison, and A. W. Kim, "Polycyclic aromatic hydrocarbons (PAHs) and polychlorinated biphenyls (PCBs) in sediments from the Mersey Estuary, UK," Science of the Total Environment, vol. 374, no. 1, pp. 112-126, 2007.

[53] H. H. Soclo, P. Garrigues, and M. Ewald, "Origin of polycyclic aromatic hydrocarbons (PAHs) in coastal marine sediments: case studies in Cotonou (Benin) and Aquitaine (France) Areas," Marine Pollution Bulletin, vol. 40, no. 5, pp. 387-396, 2000.

[54] N. Itoh, S. Tamamura, T. Sato, and M. Kumagai, "Elucidation of polycyclic aromatic hydrocarbon sources in the sinking particles in Lake Biwa, Japan," Limnology, vol. 11, no. 3, pp. 241250, 2010.

[55] M. B. Yunker, R. W. Macdonald, R. Vingarzan, R. H. Mitchell, D. Goyette, and S. Sylvestre, "PAHs in the Fraser River basin: a critical appraisal of PAH ratios as indicators of PAH source and composition," Organic Geochemistry, vol. 33, no. 4, pp. 489-515, 2002.

[56] P. Baumard, H. Budzinski, P. Garrigues, J. C. Sorbe, T. Burgeot, and J. Bellocq, "Concentrations of PAHs (polycyclic aromatic hydrocarbons) in various marine organisms in relation to those in sediments and to trophic level," Marine Pollution Bulletin, vol. 36, no. 12, pp. 951-960, 1998.

[57] K. Booij, M. T. Hillebrand, R. F. Nolting, and J. V. Ooijen, "Nutrients, trace metals, and organic contaminants in Banten Bay, Indonesia," Marine Pollution Bulletin, vol. 42, no. 11, pp. 1187-1190, 2001. 

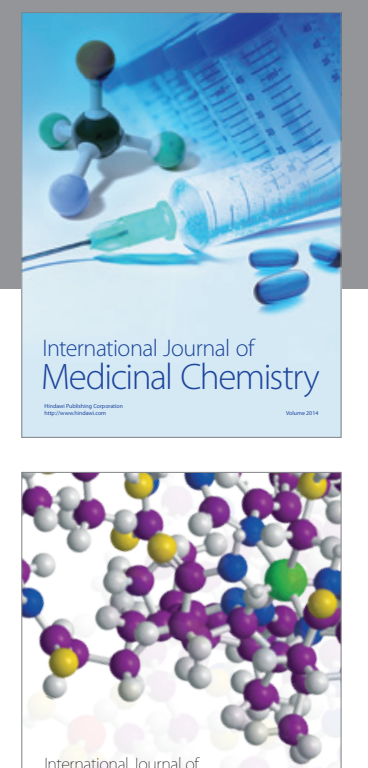

\section{Carbohydrate} Chemistry

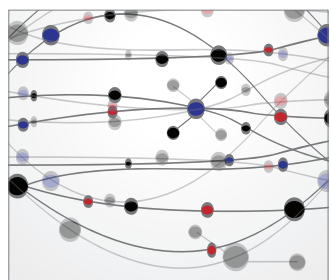

The Scientific World Journal
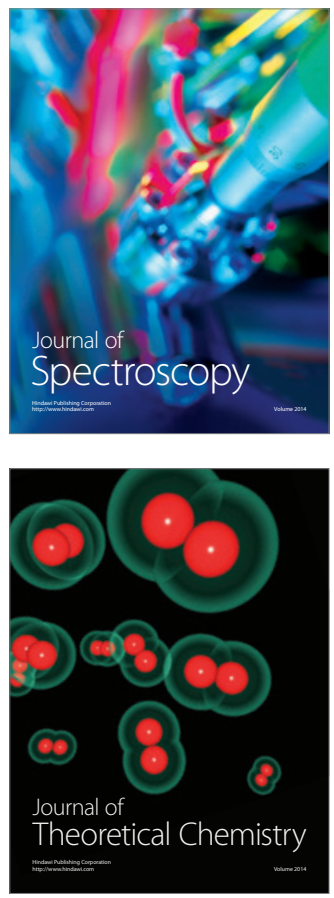
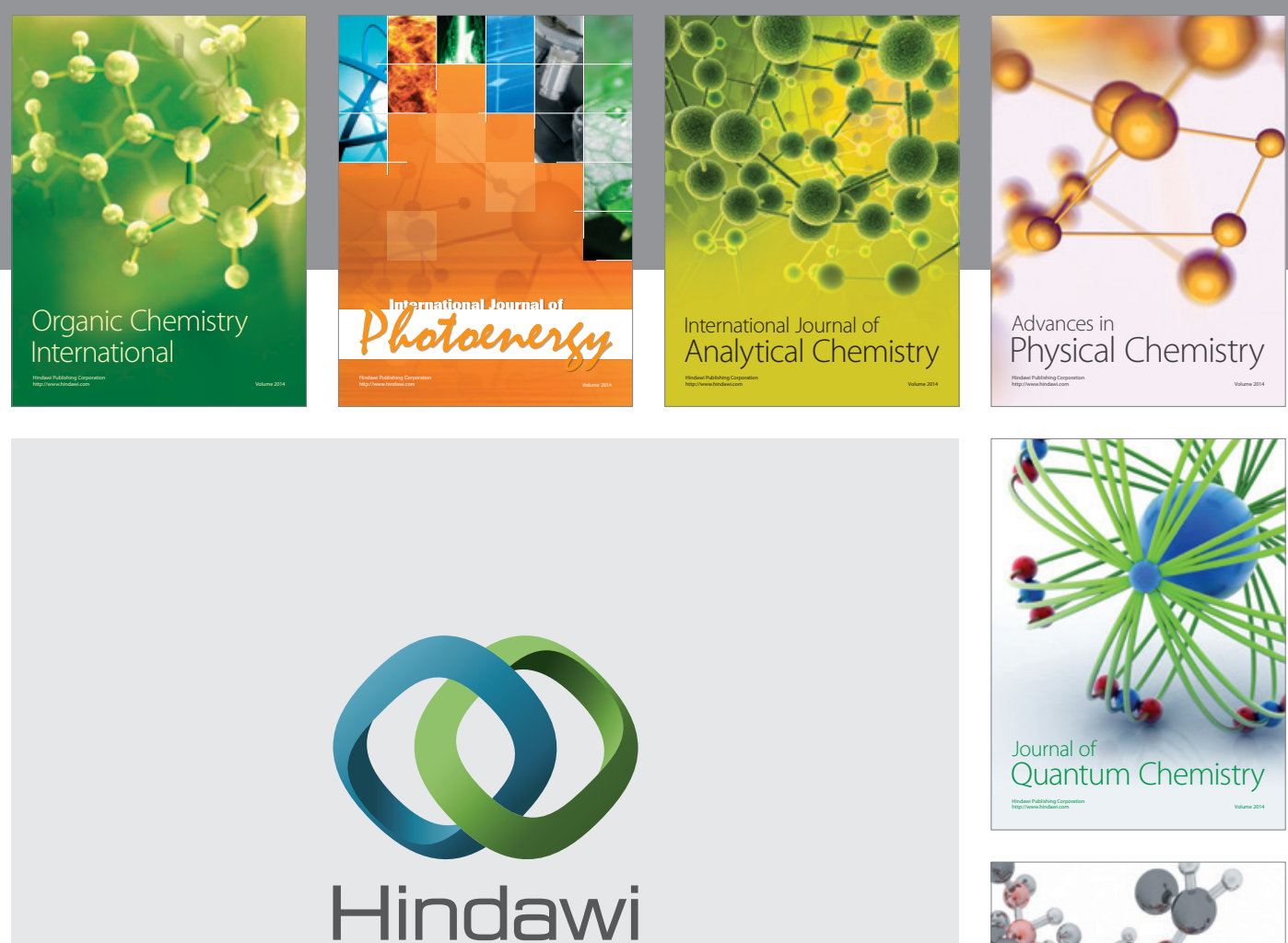

Submit your manuscripts at

http://www.hindawi.com

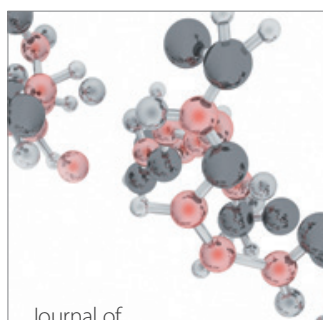

Analytical Methods

in Chemistry

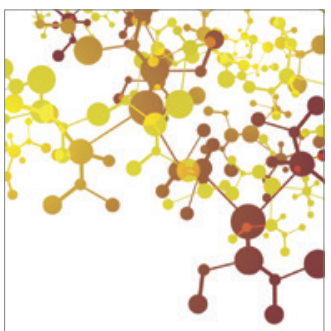

Journal of

Applied Chemistry

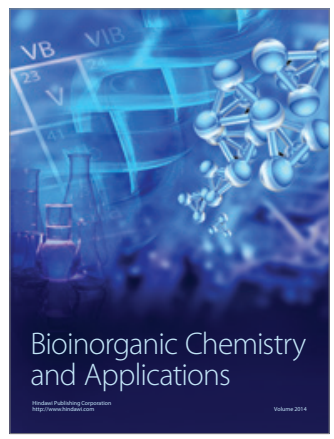

Inorganic Chemistry
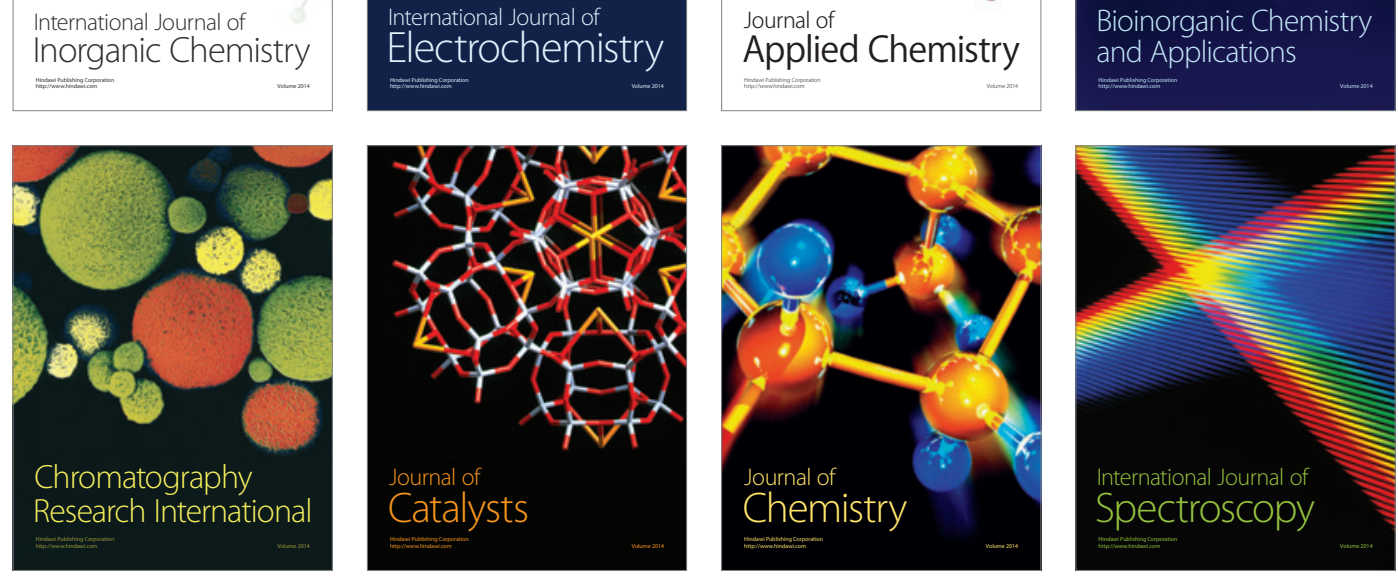